\title{
The sorption of lysozyme and ribonuclease onto ferromagnetic nickel powder 1. Adsorption of single components
}

\author{
Hwai-Shen Liu *, Yu-Chi Wang, Wen-Yih Chen ${ }^{1}$ \\ Department of Chemical Engineering, National Taiwan University. Taipei, Taiwan. Republic of China \\ Received 8 November 1994; accepted 30 January 1995
}

\begin{abstract}
The adsorption behavior of lysozyme and ribonuclease on nickel powder was studied to elucidate the effects of hydrophobicity, structural stability, and electrostatic forces. The results indicated that the equilibrium between proteins and nickel can be reached in about $20 \mathrm{~min}$ and some "overshoot" phenomena in adsorption were found. Maximal adsorption at the IEP, which could result in multilayer adsorption, was also noticed. A reduction in adsorption due to ionic shielding was observed for $\mathrm{Cl}^{-}$and $\mathrm{SCN}^{-}$, while the addition of ethanol promoted adsorption. FT-IR/ATR spectra were used to monitor the conformational changes during the adsorption process.
\end{abstract}

Keywords: Adsorption; Ferromagnetic nickel powder; Lysozyme; Ribonuclease

\section{Introduction}

The behavior of proteins at interfaces has been investigated over the last few decades. A number of recent reviews [1-3] and symposium proceedings $[4,5]$ describe this subject.

Proteins are often adsorbed spontaneously, resulting in a change in the interfacial properties. This phenomenon is related to problems such as the biocompatibility [6] of artificial implants, plaque formation on teeth, and many others. However, proteins are also adsorbed on purpose, as in the application of immobilized enzymes, diagnosis, and immunosensors [7]. Because many investigations of protein adsorption have empha-

\footnotetext{
* Corresponding author.

${ }^{1}$ Present address: Department of Chemical Engineering, National Central University, Chung-Li, Taiwan.
}

sized the phenomenological aspects, a systematic and detailed study is still needed.

The types of adsorbents usually studied are polystyrene (PS), PS/hydroxyethylmethacrylate, PS/acryamide [8], polyoxymethylene [9], $x-\mathrm{Fe}_{2} \mathrm{O}_{3}$ $[10]$, and calcium hydroxyapatite [11]. If the purpose is to find a rapid, efficient method of separating a protein-adsorbent complex other than filtration and centrifugation, magnetic forces may provide an alternative. The high gradient magnetic separator (HGMS) system has been in operation for many years [12]. It has been used to separate yeast [13], viruses [14], bacteria [15], algae [16], and red tide plankton [17], and related magnetic supports have been applied to recycle yeast in fermentation [18], to cultivate plant cells in magnetically stabilized fluidized beds [19], and to immobolize enzyme [20]. Among the ferromagnetics, nickel ( $\mathrm{Ni}$ ) powder has been shown to retain the activity of proteins such as lysozyme [21] and 
to act as a feasible agent to coagulate as well as to detach segregated yeast cells by $\mathrm{pH}$ reversal [22]. Therefore, the fundamental phenomena of the interaction of proteins with ferromagnetic materials, such as $\mathrm{Ni}$, and the effect of $\mathrm{pH}$ and ions on protein adsorption, etc., are worth investigating.

Generally, when metal makes contact with water, its surface is covered with oxides, hydroxide and other complexes that often undergo electrostatic interactions with adsorbates. For uncharged, randomly coiled polymers, a theory is available which describes adsorption [23]. A successful attempt has been made to correlate electrostatic interaction with polymer adsorption. However, the conformation of proteins is much more complex than that of polymers. The three-dimensional structure of a protein is the result of various interactions (electrostatic interactions, hydrophobic interactions, hydrogen bonding, disulfide bonding, etc.) within the protein molecule, as well as between the protein and its surroundings. Therefore, the existing theories on polymer adsorption seem insufficient to explain the interfacial phenomenon of protein adsorption. Many studies have pointed out the significance of electrostatic interactions between the adsorbate and the adsorbent surface, for instance, amino acids [24], polypeptides [25], small anions [26], polyanions [27], and surfactants [28]. However, electrostatic interactions do not fully account for the adsorption of proteins [29]. For example, some proteins can adsorb onto a surface that carries the same charge $[1,30]$. A detailed study of human plasma albumin adsorption indicated that the main driving force for the adsorption process is entropy gain [31,32], which always results from structural rearrangement, changes in hydration, and co-adsorption of electrolytes. Because of the specificity and complexity of protein conformation, it is difficult to systematically draw unambiguous conclusions about the effect of the intrinsic properties of proteins. Nevertheless, some trends are emerging from literature data: (1) adsorption is enhanced by increasing the hydrophobicity of the protein, with its stability playing an important role [33]; (2) overall electrostatic interactions are important for small proteins
[8]. The involvement of small ions in the adsorption process is discussed elsewhere [34,35].

The aim of this work is to investigate the adsorption of lysozyme and ribonuclease (RNase) onto $\mathrm{Ni}$ powder. Lysozyme and RNase have respective molecular weights of 14600 and 13680 , dimensions of $4.5 \times 3.0 \times 3.0 \mathrm{~nm}$ and $3.8 \times 3.8 \times 2.2 \mathrm{~nm}$, and isoelectric points (IEPs) of around 11 and $7.8 \mathrm{pH}$ units [7]. Lysozyme has been reported to have a higher structural stability and hydrophobicity (both overall and surface) than RNase [9]. Given the similar molecular weights, sizes, and shapes of the proteins, the differences in hydrophobicity, electrical charge, and conformational stability were taken as experimental variables. Comparative studies of these two proteins may contribute to a further understanding of the roles of surface charge, hydrophobicity, and protein structure in the behavior of proteins at interfaces.

\section{Materials and methods}

\subsection{Materials}

\section{Proteins}

Lysozyme and RNase were purchased from Merck. Their general properties can be found in Ref. [9], and the IEPs are $\mathrm{pH}$ 10.5-11 for lysozyme and $\mathrm{pH} 8$ for RNase according to the Merck Index.

\section{Ni powder and chemicals}

$\mathrm{Ni}$ powder from Ferak was pre-washed and dried at room temperature. The mean particle diameter of $\mathrm{Ni}$ was measured as $4.8 \mu \mathrm{m}$ (by MALVERN system $4700 \mathrm{c}$ ) with a BET surface area of $0.82 \mathrm{~m}^{2} \mathrm{~g}^{-1}$ (by Micromeritics ASAP2000 system). The pore surface area, about $0.008 \mathrm{~m}^{2}$ $\mathrm{g}^{-1}$, of this Ni powder was also determined, using mercury porosimetry (Micromeritics Autopore 9220 system) based on the theory of the capillary governing liquid penetration into small pores. The electrophoretic mobilities of bare Ni powder determined by a MALVERN zetasizer are discussed later in Fig. 6. Deionized water was obtained from Milli-RO plus and Barnstead NANOpure II purification systems. Other chemicals were of reagent grade or better. 
Assay

The protein concentrations in the solution were determined by UV $280 \mathrm{~nm}$ after settling the $\mathrm{Ni}$ powder by a magnet and a centrifuge $(1000 \mathrm{~g}$, for 5 min). It was estimated that, by Stokes' law, the $\mathrm{Ni}$ powder would settle within $1 \mathrm{~s}$ under this centrifugal field without pre-settlement by a magnet. A two-step method was used to ensure complete removal of the Ni powder. Fourier transform-infrared spectroscopy (FT-IR)/ attenuated total reflection (ATR) by a Perkin-Elmer (Model 2000 ) spectrometer was used to monitor the conformational change in the proteins during the absorption process.

Polypropylene bottles were used as containers throughout the study for the negligible protein adsorption [29]. All the experiments were conducted in a water-bath shaker at 250 r.p.m. to ensure uniform suspension of the Ni powder.

\subsection{Experimental procedure}

\section{Protein adsorption kinetics curve}

Lysozyme and RNase solutions were prepared by dissolving the appropriate amount in a $0.005 \mathrm{M}$ phosphate buffer. The desired $\mathrm{pH}$ was adjusted by $\mathrm{NaOH}$ or $\mathrm{HCl}$, their effect on ionic strength being less than $1 \%$ throughout this study. Pre-washed and dried Ni powder was then added to the protein solution, which was shaken at 250 r.p.m. The adsorbed amount of protein at various time periods was obtained by measuring the difference between the initial and the residual protein concentration in the solution.

\section{Adsorption isotherms of single protein}

An appropriate amount of protein was dissolved in a $0.005 \mathrm{M}$ buffer solution at the desired $\mathrm{pH}$. The solution was then equally divided into several polypropylene bottles each of $5 \mathrm{ml}$ (A). Ni powder $(0.5 \mathrm{~g})$ was added to $45 \mathrm{ml}$ of buffer solution at the same pH (B). The samples of protein solution (A) were then added progressively to the Ni suspension (B) after the previous protein addition had reached equilibrium. By sampling a clear aliquot of the whole solution with the aid of a magnet, the nonadsorbed protein concentration in the solution was measured when equilibrium had been reached after each addition, to determine the adsorbed amount. The purpose of this method, in contrast to a classical approach with an individual sample for each point of the adsorption isotherm, is to avoid the data fluctuation due to different batches of $\mathrm{Ni}$ powder. A set of adsorption isotherms for each protein was obtained for various $\mathrm{pH}$ values and salt additions. Adsorption data for an organic solvent (ethanol) addition and various salt additions as a function of $\mathrm{pH}$ were also obtained.

\section{Results and discussion}

\subsection{Adsorption kinetics curve}

The time courses of adsorption are shown in Figs. 1(A) (lysozyme, pH 10.5) and I(B) (RNase. pH 7.8) for various initial concentrations. "Overshoot" phenomena were observed, and equilibrium was established in about $20 \mathrm{~min}$. Compared with $2-3 \mathrm{~h}$ for most polymer adsorbents [36], this fast adsorption could be an advantage for separation, and may be attributed to the negligible pore diffusion resistance of $\mathrm{Ni}$ powder (pore surface area/BET surface area $<1 \%$ ). In Fig. $1(\mathrm{~A})$ of the lysozyme adsorption kinetic curve, a similar tendency was observed for all the concentrations. However, the "overshoot" of RNase adsorption in Fig. 1(B) at $70 \mathrm{mg}^{-1}$ initial concentration was smoother than for the other two curves. This could have resulted from the relatively fragile structure of RNase and the low concentration, giving the adsorbed R Nase molecules sufficient "elbow room" [37] and an easier conformational change to adapt to their new microenvironment. Thus, one R Nase molecule would occupy more empty sites, and the free RNase would not easily attach to the adsorbent surface, resulting in a smoother "overshoot".

Soderquist and Walton [38] have suggested that during the early stages, the rate of protein adsorption is rapid and reversible, and the adsorbent surface can be considered as a perfect sink [39]. so the protein is adsorbed in a random arrangement. Afterwards, adsorbed protein molecules undergo a conformational change that leads to surface interactions. Proteins less optimally adsorbed may be desorbed from the surface. and 

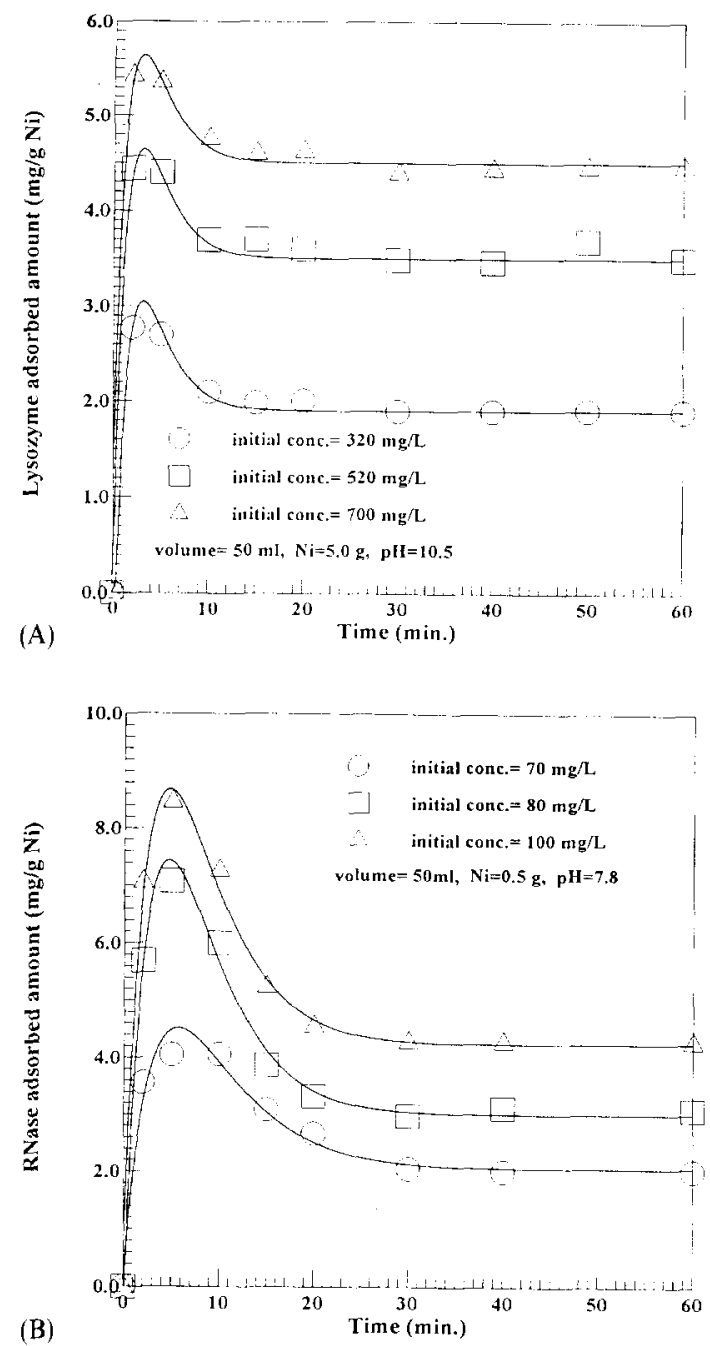

Fig. 1. Time dependence of adsorption: (A) lysozyme; (B) RNase.

"overshoot" phenomena may accordingly appear. The desorption experiments in the companion article [41b] also indicated that the protein is more likely to be desorbed during the "overshoot" period, implying that some irreversible conformational change may occur.

Fig. 2. Adsorption isotherms for lysozyme: (A) buffer without $\mathrm{NaCl}$ or $\mathrm{NaSCN}$; (B) buffer with $0.1 \mathrm{M} \mathrm{NaCl}$; (C) buffer with $0.1 \mathrm{M} \mathrm{NaSCN}$.
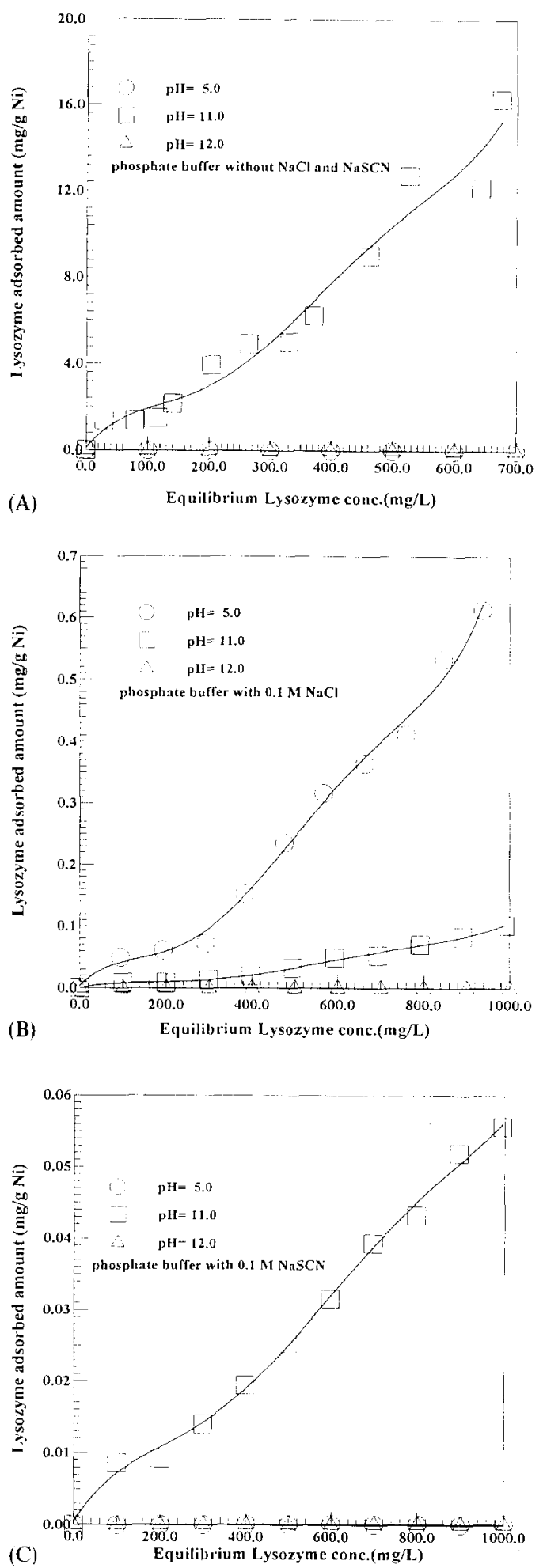


\subsection{Adsorption isotherms of single protein}

The adsorption isotherms of individual proteins on $\mathrm{Ni}$ powder are given in Figs. 2(A) (lysozyme without salt), 2(B) (lysozyme with $0.1 \mathrm{M} \mathrm{NaCl}$ ), 2(C) (lysozyme with $0.1 \mathrm{M} \mathrm{NaSCN}$ ), 3(A) (RNase without salt), 3(B) (RNase with $0.1 \mathrm{M} \mathrm{NaCl}$ ), and 3(C) (RNase with $0.1 \mathrm{M} \mathrm{NaSCN}$ ) for various $\mathrm{pH}$ values. It can be seen that optimum adsorption occurred around the IEPs for each protein without salt addition, i.e. about $\mathrm{pH} 11$ for lysozyme (Fig. 2(A)) and $\mathrm{pH} 8$ for RNase (Figure 3(A)). A rough estimate of monolayer adsorption would be in the order of $1 \mathrm{mg}$ of protein per $\mathrm{g}$ of $\mathrm{Ni}$ at most. For these two isotherms at each IEP, the adsorption amounts for both proteins obviously exceeded the values of monolayer coverage. The higher affinity between lysozyme and the Ni surface could be due to the higher hydrophobicity of lysozyme. It was also observed that these two isotherms (pH 11 in Fig. 2(A) and pH 8 in Fig. 3(A)) tended to become concave until a "step" or "kink" [8] appeared. This probably reflects a conformational rearrangement of adsorbed protein molecules into a more compact and ordered structure or stack from the monolayer to the multilayer. This kind of isotherm. sometimes termed the sigmoid or S-shaped isotherm [40], is commonly encountered with non-porous adsorbents or macroporous materials. which can be justified by the $<1 \%$ pore surface area of the BET surface. The addition of salt such as $\mathrm{NaCl}$, or especially $\mathrm{NaSCN}$, can greatly reduce the adsorption, as shown in Figs. 2(B), $2(\mathrm{C}), 3(\mathrm{~B})$, and $3(\mathrm{C})$. This tendency to reduce adsorption is consistent with the chaotropic series defined by Porath [41a], which is the same as the Hofmeister series. The increase in desorption on addition of $\mathrm{NaSCN}$, which will be discussed in the companion article [41b] also confirms this result.

\subsection{Effect of $\mathrm{pH}$ and ionic concentration}

When the application of protein separation, bioreactors, etc., is considered, protein adsorption

Fig. 3. Adsorption isotherms for RNase: (A) buffer without $\mathrm{NaCl}$ or NaSCN; (B) buffer with $0.1 \mathrm{M} \mathrm{NaCl}$; (C) buffer with $0.1 \mathrm{M}$ NaSCN.

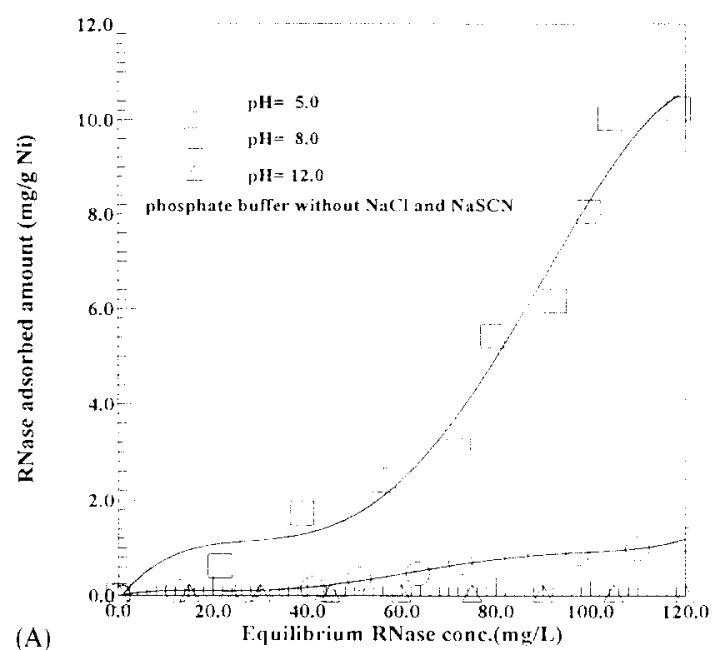

(A)

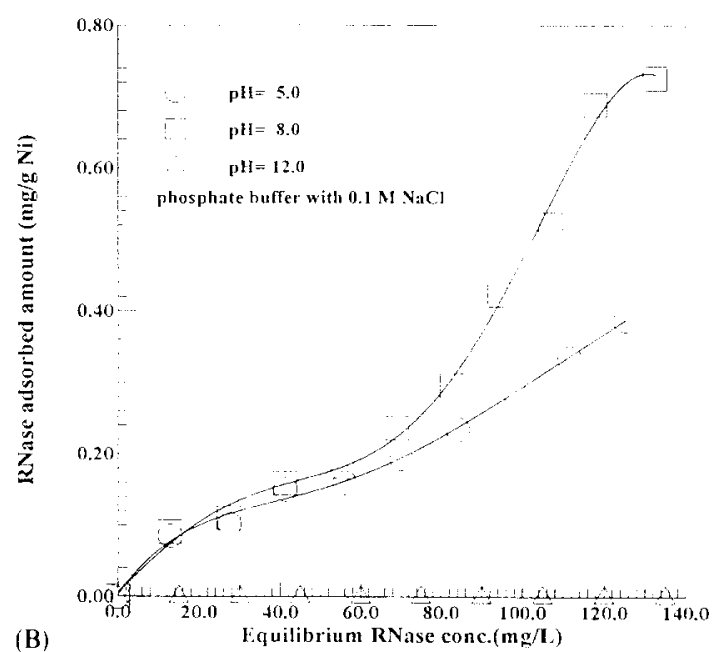

(B)

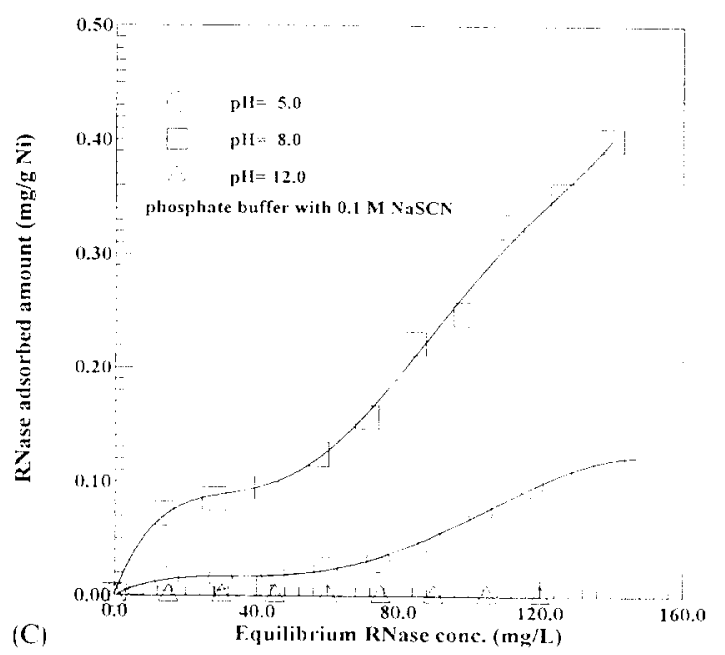


must be investigated over a wider range of $\mathrm{pH}$ and ionic concentrations. Figs. 4(A) and 4(B) show the $\mathrm{pH}$ dependence of lysozyme and RNase adsorption at $\mathrm{NaCl}$ concentrations of $0,0.01$, and $0.1 \mathrm{M}$. In these Figures, adsorption tends to be at the maximum near the IEP of each protein. This may be because of a minimum electrostatic repulsion among protein molecules and the higher structural stability at their IEP [42], as well as strong adsorption leading to unfolding at one side of the IEP and repulsion at the other side [43]. However, the $\mathrm{pH}$ of maximum adsorption shifts to a more acidic $\mathrm{pH}$ with increasing $\mathrm{NaCl}$ concentration. This phenomenon could be related to the shift of IEP towards an acidic $\mathrm{pH}$ on addition of $\mathrm{NaCl}$ [8]. Also, ions could cover the protein molecule and the Ni surface to form an ion shield [9], a barrier caused by electrostatic interactions. In addition, an increase in ionic strength could lower the diffusivity of proteins and enlarge the absorbed protein molecules, which would thus occupy a greater area of the $\mathrm{Ni}$ surface $[44,45,46]$. Therefore, the increase in $\mathrm{NaCl}$ concentration inhibited protein adsorption, as shown in Fig. 4 for both proteins. The effects of salt in Fig. 4 were more significant for RNase, which could be explained by the higher hydrophobicity of lysozyme. In addition to the solubility of protein, the adsorption of the less hydrophobic protein was due mainly to the electrostatic forces between protein and Ni powder. Therefore, the decrease in the electrostatic attraction between $\mathrm{Ni}$ and RNase clearly affected the amount of RNase adsorbed.

Similar trends could be observed on addition of $\mathrm{NaSCN}$, as shown in Figs. 5(A) (lysozyme) and 5(B) (RNase), although $\mathrm{SCN}^{-}$had a stronger effect on adsorption inhibition. In addition, Fig. 6 shows the effect of electrolyte anions $\left(\mathrm{Cl}^{-}\right.$and $\mathrm{SCN}^{-}$) on the electrophoretic mobilities of bare Ni powder as a function of $\mathrm{pH}$. This result indicates that the mobilities of bare $\mathrm{Ni}$ powder decrease with the addition of anions, especially $\mathrm{SCN}^{-}$, which is consistent with the foregoing discussion.

In Figs. 4 and 5, it can also be seen that when the $\mathrm{pH}$ moved away from the corresponding IEP, the adsorption of lysozyme decreased from the maximum more sharply than that of RNase. This may be due to the relative structural instability of
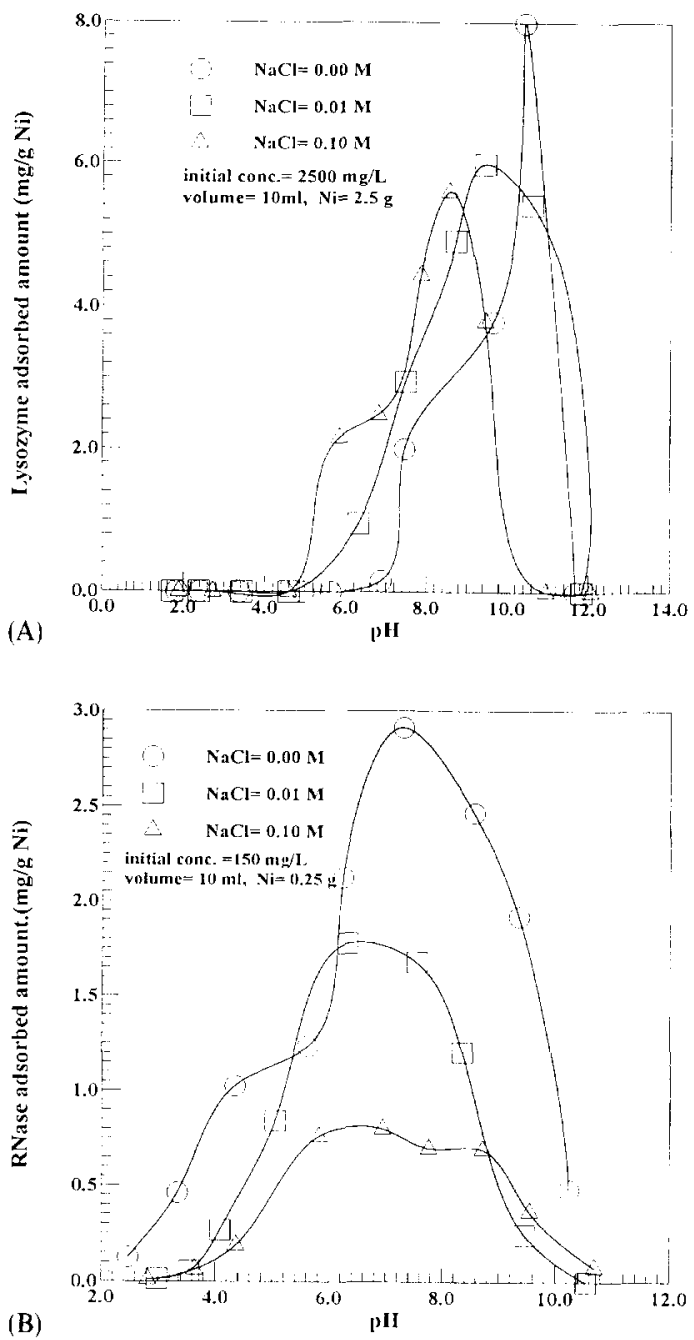

Fig. 4. Influence of $\mathrm{pH}$ on adsorbed amount: (A) lysozyme; (B) RNase.

RNase, and its ability to change conformation to fit its surroundings during the adsorption process. The FT-IR/ATR spectra of these two proteins during the adsorption process are shown in Figs. 7(A) (lysozyme, $800 \mathrm{mg}^{-1}$ at $\mathrm{pH} \mathrm{11)}$ ) and $7(\mathrm{~B})$ (RNase, $800 \mathrm{mg} \mathrm{l}^{-1}$ at $\mathrm{pH} 8$ ) for the time periods of 5,15 and $30 \mathrm{~min}$, and $24 \mathrm{~h}$. Generally, the amide III spectral region is particularly useful for distinguishing secondary structures, since $\alpha$-helix amide III vibrations are stronger in the infrared. Anderle and Mendelsohn [47] observed seven bands between 1260 and $1320 \mathrm{~cm}^{-1}$, particularly 1315 , 

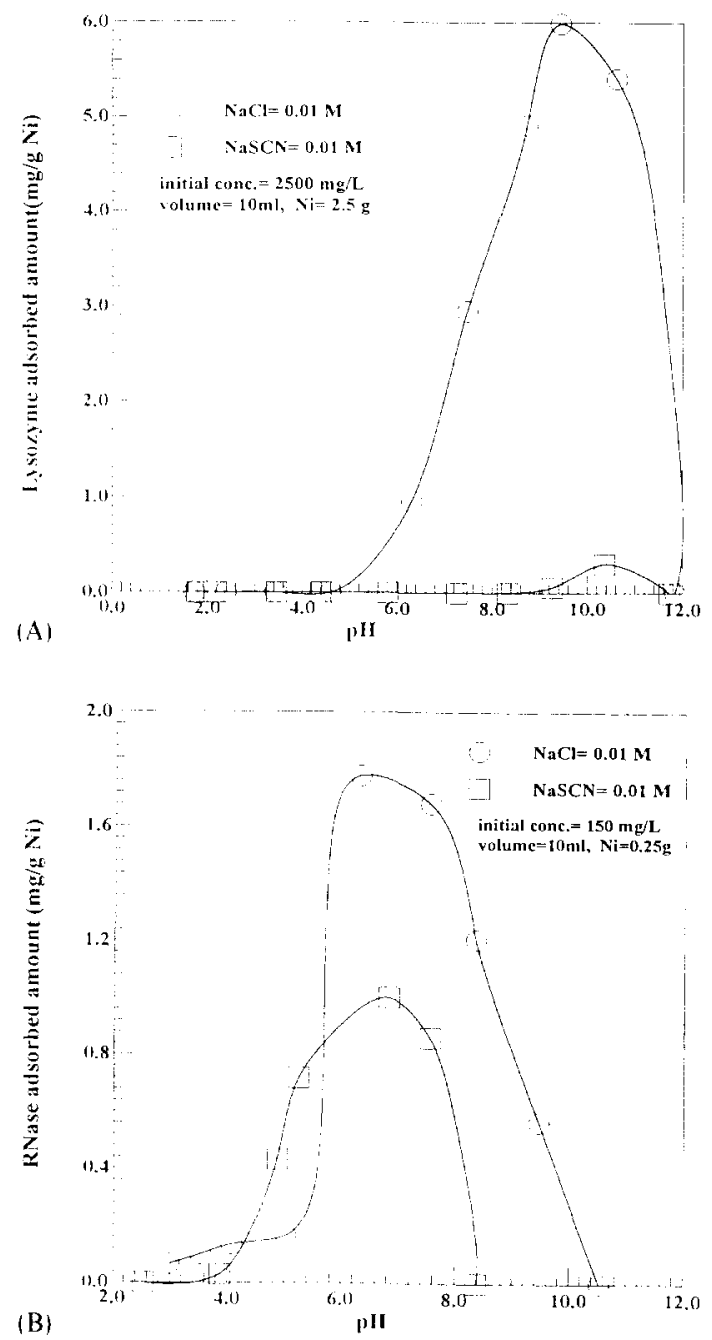

Fig. 5. Influence of anion $\left(\mathrm{Cl}^{-}\right.$and $\left.\mathrm{SCN}^{-}\right)$on adsorption: (A) lysozyme; (B) RNase.

1300 , and $1270 \mathrm{~cm}^{-1}$, which they felt had amide III helical characteristics. It can be noted that bands at 1315,1300 , and $1270 \mathrm{~cm}^{-1}$ of the RNase spectrum (Fig. 6(B)) showed a violent peak fusion and slit, but that of lysozyme (Fig. 6(A)) did not change much. This confirms that RNase has a more fragile structure and can change its conformation during the adsorption process.

\subsection{Effect of organic solvent, ethanol}

Dehydration between the adsorbent surface and protein, on addition of organic solvent, has often

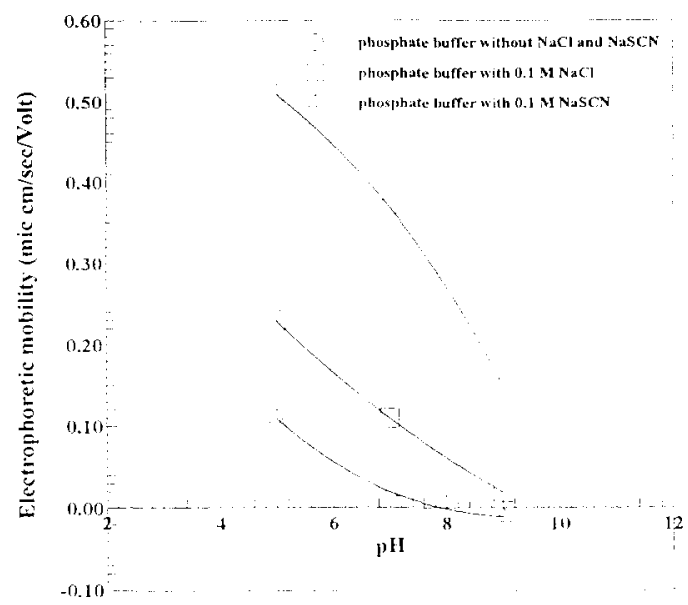

Fig. 6. Electrophoretic mobility as a function of $\mathrm{pH}$ and anion for bare $\mathrm{Ni}$ powder.

been thought to be the driving force for protein adsorption. The positive correlation between the binding affinity of protein and its hydrophobicity has also often been observed [48-53]. Pure water, whose dielectric constant is 76 , is a highly polar solvent which can prevent two particles of opposite charges from coming together. This dielectric constant can be reduced by addition of ethanol; reportedly, the effect is inversely proportional to the volume added [54]. Therefore, it is not surprising to observe an enhancement in adsorption on addition of ethanol, shown as a function of $\mathrm{pH}$ in Figs. 8(A) (lysozyme) and 8(B) (RNase). However. the hydrophobicity of a solution increased by the addition of an organic solvent could push proteins into the solid phase and enhance adsorption.

\section{Conclusion}

The adsorption characteristics of individual proteins (i.e. lysozyme and R Nase) of similar molecular size and shape on ferromagnetic powder, $\mathrm{Ni}$, were investigated. Fundamental phenomena studied included the concentration and type of electrolytes, $\mathrm{pH}$ value, organic solvent, adsorption kinetic curve, adsorption isotherms, and electrophoretic mobilities of bare Ni powder. The hydrophobicity, charge, and structural stability of both protein molecules as well as the adsorbent were taken into consider- 

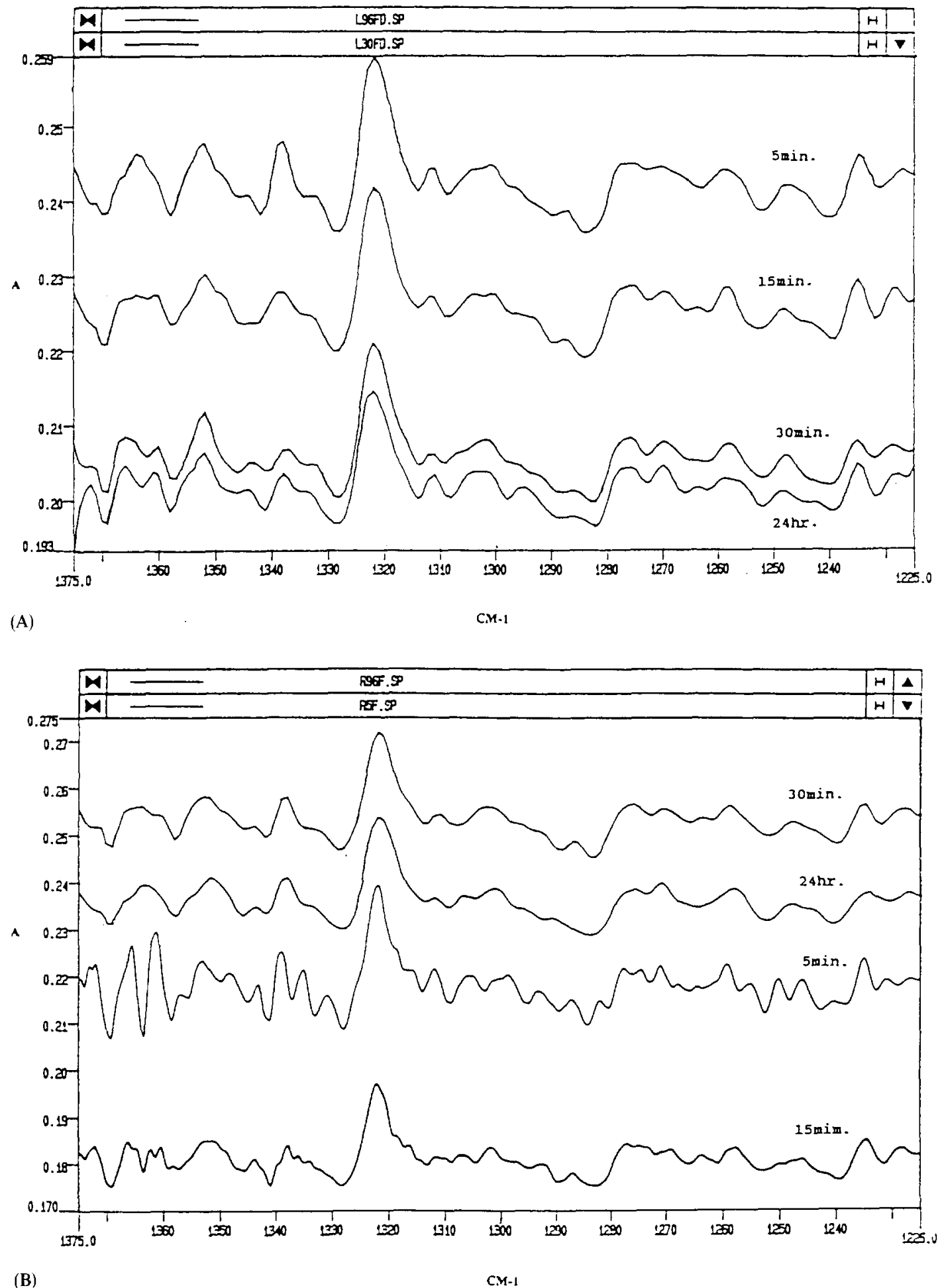

Fig. 7. Deconvoluted FT-IR/ATR spectra of protein adsorption onto Ni for various time periods: (A) lysozyme; (B) RNase 

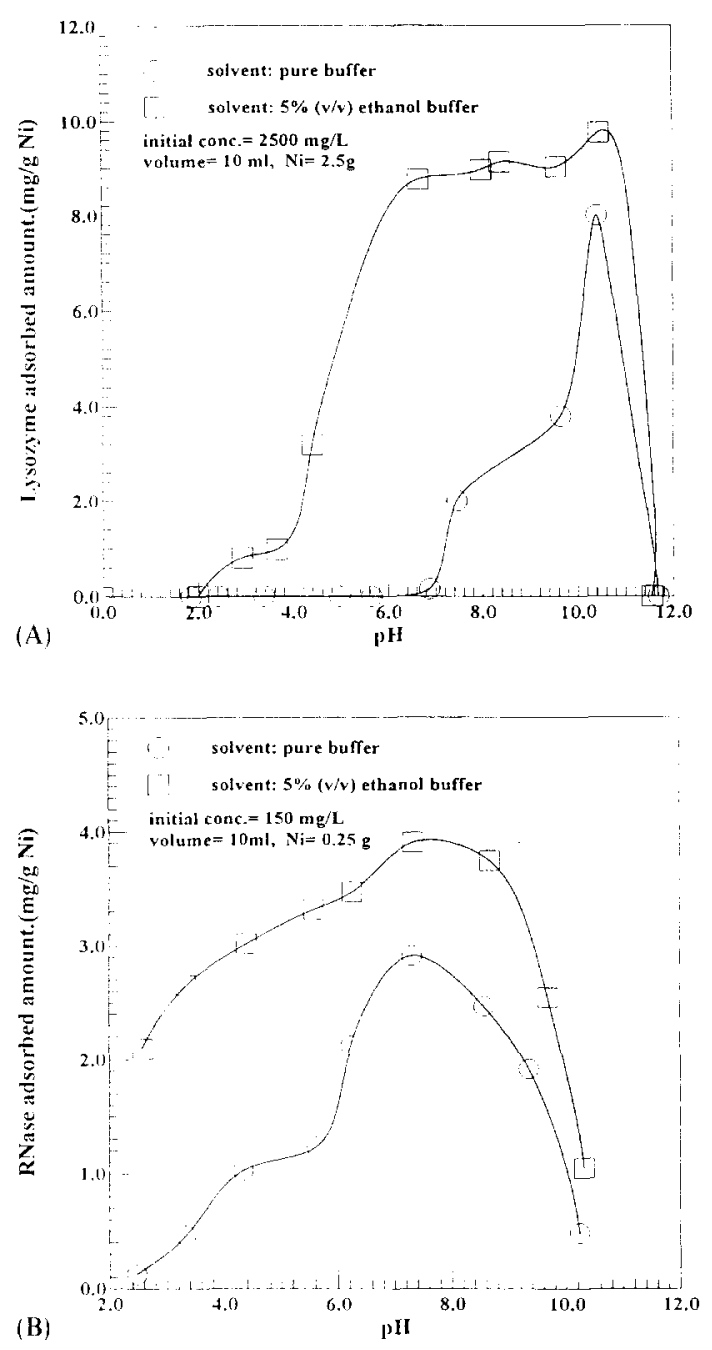

Fig. 8. Effect of organic solvent, ethanol, on adsorption: (A) lysozyme; (B) RNase.

ation. The adsorption kinetic curves of lysozyme and RNase showed "overshoot", and the adsorption isotherms showed "kinks" or "steps" that probably resulted from conformational change. The FT-IR/ATR spectra at different adsorption stages showed that the proteins underwent some conformational change, i.e. the $\alpha$-helix content was gradually reduced, especially for RNase. The plot of protein adsorption vs. $\mathrm{pH}$ indicated a maximum value near the respective IEP of the protein, and the adsorption curves were more or less symmetrical to the IEP. However, for lysozyme the adsorbed amount dropped sharply from the maximum, while that for RNase did not. The reason for this may be the better structural stability of lysozyme. It was also found that ions could form an ionic shield between the protein and the $\mathrm{Ni}$ surface, thus inhibiting protein adsorption. This finding was further supported by the electrophoretic mobilities of bare $\mathrm{Ni}$. Also, the generally positive correlation between the extent of protein adsorption and dielectric constant reduction was again confirmed. The addition of ethanol to lower the dielectric constant, i.e. to enhance the hydrophobicity of the protein molecules and reduce the hindrance of the water molecule between protein-protein and protein- $\mathrm{Ni}$, increased the adsorbed amount. The behavior of protein desorption and adsorption of the protein mixture will be explored in the companion article to this one $[41 \mathrm{~b}]$.

\section{Acknowledgment}

The authors gratefully acknowledge the support of the National Science Council, Taiwan, Republic of China.

\section{References}

[1] W. Norde, Adv. Colloid Interface Sci., 25 (1986) 267.

[2] B. Ivarsson and I. Lundstrom, CRC Crit. Rev. Biocompat., 2 (1985) 1.

[3] J.D. Andrade and V. Hlady, Adv. Polym. Sci., 79 (1986) 1.

[4] D.W. Fuerstenau, S. Chander, J. Lin and G.D. Parfitt, ACS Symp. Ser., 311 (1984).

[5] R.M. Gendreau and A. Sugitachi, ACS Symp. Ser., 371 (1982).

[6] F.J. Holly, J. Polym. Sci., Polym. Symp., 66 (1979) 409.

[7] Y.D. Clonis, Biotechnology, 5 (1987) 1290.

[8] T. Suzwa and H. Shirahama. Adv. Colloid Interface Sci., 35 (1991) 139 .

[9] T. Arai and W. Norde, Colloids Surfaces. 51 (1990) 1.

[10] P.G. Koutsoukos, W. Norde and J. Lyklema, J. Colloid Interface Sci., 95 (1983) 385.

[11] V. Hlady and H.F. Milhofer, J. Colloid Interface Sci., 69 (1979) 460 .

[12] P. Anand, J.E. Etzel and F.J. Fridlaender, IEEE Trans. Magnet., 21 (1985) 2062.

[13] R.R. Dauer and E.H. Dunlop. Biotech. Bioeng. 37 (1991) 1021 .

[14] C. Bitton and R. Mitchell, Water Res.. 8 (1974) 549. 
[15] J.R. Harland, J.A. Oberteuffer and D.J. Goldstein, Chem. Eng. Prog., October (1976) 79.

[16] C. de Latour, Ph.D. Thesis, MIT, Boston, MA, 1974.

[17] S. Korinobu and S. Uchiyama, IEEE Trans. Magnet., 12 (1975) 234.

[18] P.O. Larsson and K. Mosbach, Biotech. Lett., 1 (1979) 501.

[19] J.L. Bramble, D.J. Graves, P. Brodelius, The AIChE National Meeting, Washington, DC, \#26c, 1988.

[20] P.J. Halling and P. Dunnill, Biotech. Bioeng., 21 (1979) 393.

[21] A.S. Chetty and M.A. Burns, Biotech. Bioeng., 38 (1991) 963.

[22] M.G. Weeks, P.A. Munro and P.L. Spedding, Biotech. Bioeng., 25 (1983) 687.

[23] G.J. Fleer and J. Lyklema, Adsorption from Solution at the Solid-Liquid Interface, Academic Press. New York, 1983 , p. 153.

[24] E.C. Moreno, M. Kresak and D.I. Hay, Calcif. Tissue Int., 36 (1984) 48.

[25] A.C. Juriaanse, J. Arends and J.J. Ten Bosh, J. Colloid Interface Sci., 76 (1980) 212.

[26] S. Shimabayashi, H. Fukuda and T. Aoyama, Chem. Pharm. Bull., 30 (1982) 3047.

[27] E.I.F. Pearce, Calcif. Tissue Int., 33 (1981) 395.

[28] R.K. Mishra, S. Chander and D.W. Fuerstenau, Colloids Surfaces, 1 (1980) 105.

[29] A. Barroug, J. Lemaitre and P.G. Rouxhet, Colloids Surfaces, 37 (1989) 339.

[30] H. Shirahama, T. Shikuma and T. Suzawa, Colloid Polym. Sci., 267 (1989) 587.

[31] P.G. Koutsoukos, C.A. Mumme-Young and W. Norde, Colloids Surfaces, 5 (1982) 93.

[32] J. Lyklema, Colloids Surfaces, 10 (1984) 33.

[33] D. Horsley, J. Herron, V. Hlady and J.D. Andrady, ACS Symp. Ser., 343 (1987) 290.

[34] P.V. Dulm, W. Norde and J. Lyklema, J. Colloid Interface Sci., 82 (1982) 77.
[35] W. Norde, Colloids Surfaces, 10 (1984) 24.

[36] H. Shirahama, K. Takeda and T. Suzawa, J. Colloid Interface Sci., 109 (1986) 552.

[37] B.W. Morrissey, Ann. N.Y. Acad. Sci., 288 (1977) 50.

[38] M.E. Soderquist and A.G. Walton, J. Colloid Interface Sci., 75 (1980) 386.

[39] H. Motschmann, M. Stamm and Ch. Toprakcioglu, Macromolecules, 24 (1991) 3681.

[40] C.N. Satterfield, Heterogeneous Catalysis in Industrial Pratice, 2nd edn., 1991, p. 133.

[41a] J. Porath, Biotechnol. Prog., 3 (1987) 14.

[41b] H.-S. Liu and Y.-C. Wang, Colloids Surfaces B: Biointerfaces, 5 (1995) 35 .

[42] W. Norde and J. Lyklema, J. Colloid Interface Sci., 66 (1978) 257.

[43] H. Quiquampoix and R.G. Ratcliffe, J. Colloid Interface Sci., 148 (1992) 343.

[44] J.J. Ramsden and J.E. Prenosil, J. Phys. Chem., 98 (1994) 5376.

[45] V.G. Levich, Physiochemical Hydrodynamics, PrenticeHall, Eaglewood Cliffs, NJ, 1962.

[46] T.W. Healy and L.R. White, Adv. Colloid Interface Sci., 9 (1978) 303.

[47] G. Anderle and R. Mendelsohn, Biophys. J., 52(1987) 69.

[48] B.R. Young, W.G. Pitt and S.L. Copper, J. Colloid Interface Sci., 124 (1988) 28.

[49] B.R. Young, W.G. Pitt and S.L. Copper, J. Colloid Interface Sci., 125 (1988) 246.

[50] U. Jonsson, B. Ivarsson, I. Lundstrom and L. Berghem, J. Colloid Interface Sci., 90 (1982) 148.

[51] S.A. Darst, C.R. Robertson and J.A. Berzofsky, Biophys. J., 53 (1988) 533.

[52] H. Elwing, S. Welin, A. Askendal, U. Nilsson and I. Lundstrom, J. Colloid Interface Sci., 119 (1987) 203.

[53] R.K. Scopes, Protein Purification, 2nd edn., SpringerVerlag, New York, 1987, p. 55.

[54] R.D. Tilton, C.R. Robertson and A.P. Gast, Langmuir, 7 (1991) 2710 . 